\title{
Penerapan Metode Problem Based Learning Pada Mata Pelajaran IPS Untuk Meningkatkan Minat Dan Hasil Belajar
}

\author{
Fatrah Kaharu \\ Guru SMP Negeri 1 Buntulia Gorontalo \\ fatrah@gmail.com
}

Received: 04 Januari 2021; Revised: 26 Februari 2021; Accepted: 28 April 2021 DOI: http://dx.doi.org/10.37905/aksara.7.2.507-522.2021

\begin{abstract}
Abstrak
Hasil penelitian dapat disimpulkan sebagai berikut: 1) Penerapan metode pembelajaran Problem Based Learning dapat meningkatkan minat belajar siswa dalam pembelajaran IPS dikelas VIII B SMP Negeri 1 Buntulia. Hal tersebut dibuktikan dengan adanya peningkatan rata-rata persentase indikator minat belajar siswa setiap siklusnya. Pada siklus I rata-rata persentase indikator minat belajar siswa adalah $61 \%$. Pada siklus II menjadi $80 \%$ atau mengalami peningkatan sebesar 19\%. Hal ini berarti bahwa rata-rata persentase indikator minat belajar siswa telah melampaui kriteria keberhasilan tindakan yang ditetapkan yaitu 75\%.2) Penerapan metode pembelajaran Problem Based Learning dapat meningkatkan hasil belajar siswa. Hal ini dibuktikan dengan persentase siswa yang mencapai nilai KKM pada siklus I sebesar $61,90 \%$ meningkat menjadi $82 \%$ pada siklus II.

Hal ini berarti bahwa jumlah siswa yang mencapai nilai KKM (70) telah melampaui kriteria keberhasilan yang ditetapkan yaitu $75 \%$.

Kata Kunci: Problem Based Learning, Minat Belajar Siswa, Pembelajaran IPS
\end{abstract}

\begin{abstract}
The results of the study can be concluded as follows: 1) Application of Problem Based Learning learning methods can increase student interest in learning social studies in class VIII B SMP Negeri 1 Buntulia. This is evidenced by an increase in the average percentage of indicators of student interest in learning each cycle. In the first cycle, the average percentage of students' interest in learning indicators was $61 \%$. In the second cycle to $80 \%$ or an increase of $19 \%$. This means that the average percentage of students' interest in learning indicators has exceeded the criteria for the success of the action set, namely 75\%. 2) Application of Problem Based Learning learning methods can improve student learning outcomes. This is evidenced by the percentage of students who achieved the KKM score in the first cycle of $61.90 \%$, increasing to $82 \%$ in the second cycle. This means that the number of students who reach the KKM score (70) has exceeded the set success criteria, namely $75 \%$.

Keywords: Problem Based Learning, Student Learning Interests, Social Studies Learning
\end{abstract}

\section{PENDAHULUAN}

Ilmu Pengetahuan Sosial (IPS) sangatlah berguna untuk dijadikan suatu mata pelajaran pada jenjang pendidikan di SMP/MTs. Hal ini dikarenakan mata 
pelajaran IPS dapat menumbuhkan rasa sosial dalam bermasyarakat serta dapat memberikan sumbangsih untuk tercapainya suatu tujuan pendidikan di tingkat SMP/MTs, apalagi mata pelajaran IPS merupakan pembelajaran terpadu yang salah satunya dapat di nilai sangat penting untuk di terapkan pada zaman milenial pada saat ini untuk membentuk karakteristik dan sikap-sikap sosial yang baik pada setiap siswa melalui pembelajaran IPS.

Masih rendahnya hasil belajar IPS disebabkan oleh masih dominannya skill menghafal daripada skill memproses sendiri pemahaman suatu materi. Selama ini, minat belajar siswa terhadap mata pelajaran Ilmu Pengetahuan Sosial (IPS) masih tergolong sangat rendah. Hal ini dapat dilihat pada sikap siswa selama mengikuti proses pembelajaran tidak fokus dan ramai sendiri. Bahkan ada sebagian siswa yang menganggap mata pelajaran IPS tidak begitu penting dikarenakan tidak masuk pada mata pelajaran yang diujikan pada Ujian Nasional (UN). Faktor minat itu juga dipengaruhi oleh adanya metode mengajar yang digunakan guru dalam menyampaikan materi. Terkhusus dalam menarik minat belajar pada mata pelajaran IPS guru tersebut kurang pandai menarik perhatian siswa sehingga tidak adannya feedback antara guru dan siswa. Hal ini berdampak pada hasil belajar siswa rendah dan terlihat dari KKM 75 yang ditetapkan pihak sekolah yang bersangkutan

Hal ini dibuktikan dari banyaknya siswa yang belum mencapai KKM (Kriteria Ketuntasan Minimal). Berdasarkan nilai ulangan harian siswa kelas VIII B SMP Negeri 1 Buntulia tahun ajaran 2018/2019 pada materi interaksi keruangan dalam kehidupan di Negara - negara ASEAN, ada 14 dari 21 siswa atau 66,67\% siswa yang belum mencapai KKM, hanya 7 atau 33,33\% siswa yang telah mencapai KKM. Penggunaan metode pembelajaran dalam suatu proses pembelajaran mempunyai pengaruh yang besar dalam tercapainya tujuan pembelajaran. Penggunaan metode pembelajaran yang tepat tentunya akan berpengaruh terhadap minat belajar siswa dalam mengikuti proses pembelajaran. Minat belajar yang tinggi akan membawa perasaan senang, sehingga materi pelajaran yang disampaikan oleh guru dapat dipahami atau diserap oleh siswa. Metode pembelajaran mempunyai peranan yang sangat penting karena metode pembelajaran menjadi sarana dalam menyampaikan materi pelajaran. Tanpa metode yang tepat, maka suatu proses pembelajaran tidak akan berlangsung secara efektif dan efisien. Metode pembelajaran tersebut harus mampu mengikutsertakan semua siswa untuk berperan aktif dalam proses pembelajaran, mampu mengembangkan kemampuan siswa untuk berfikir kritis sehingga proses pembelajaran menjadi lebih menarik dan menyenangkan sekaligus dapat menumbuhkan minat belajar siswa sehingga prestasi belajar siswa diharapkan akan meningkat.

Penggunaan metode dalam pembelajaran sangat diutamakan guna menimbulkan gairah belajar, motivasi belajar, merangsang siswa berperan aktif dalam proses pembelajaran. Pengembangan metode pembelajaran tersebut sangat perlu dilakukan untuk menjawab kebutuhan keterampilan pemecahan permasalahan yang harus dimiliki oleh siswa. Salah satu metode pembelajaran yang dapat digunakan guru adalah metode pembelajaran problem based learning (PBL) Melalui metode problem based learning ini dapat melatih dan mengembangkan kemampuan untuk menyelesaikan masalah yang berorientasi pada masalah autentik 
dari kehidupan aktual siswa, untuk merangsang kemampuan berfikir tingkat tinggi. Sehingga lebih mempermudah pemahaman materi pelajaran yang diberikan dan nantinya dapat mempertinggi kualitas proses pembelajaran yang selanjutnya dapat meningkatkan minat dan hasil belajar siswa

Menurut Djaali (2007:121), minat adalah rasa lebih suka dan rasa keterikatan pada sesuatu hal atau aktivitas tanpa ada yang menyuruh. Pernyataan tersebut mengidentifikasikan bahwa orang yang berminat akan ada rasa tertarik. Tertarik dalam hal tersebut merupakan wujud dari rasa senang pada sesuatu. Menurut Djamarah (2008:166), minat berarti kecenderungan yang menetap dan mengenang beberapa aktivitas. Seseorang yang berminat terhadap aktivitas akan memperhatikan aktivitas itu secara konsisten dengan rasa senang. Agus Sujanto (2004:92) berpendapat, bahwa minat sebagai sesuatu pemusatan perhatian yang tidak sengaja yang terlahir dengan penuh kemauannya dan tergantung dari bakat dan lingkungannya

\section{KAJIAN TEORI}

\section{Minat Belajar}

Menurut Crow dan Crow yang di kutip dan diterjemahkan Kasiji Z (1984: 159-160) menyebutkan bahwa ada tiga faktor yang mendasari timbulnya minat seseorang, yaitu :

a. Faktor dorongan yang berasal dari dalam, faktor dari dalam merupakan faktor yang berasal dari dalam diri seperti harapan dan keinginan, yang mendorong pemusatan perhatian dan keterlibatan mental secara aktif.

b. Faktor motif sosial, merupakan faktor yang membangkitkan minat pada halhal yan ada hubunganya dengan kebutuhan sosial bagi dirinya.

c. Faktor emosional, merupakan intensitas seseorang dalam menaruh perhatian terhadap suatu kegiatan atau obyek tertentu

Menurut Muhibin Syah (2002:129), bahwa minat dapat mempengaruhi kualitas pencapaian hasil belajar siswa dalam bidang studi tertentu. Guru seyogyanya membangkitkan minat siswa untuk menguasai pengetahuan yang terkandung dalam bidang studinya dengan cara yang kurang lebih sama dengan membangun sikap positif.

Mengenai minat ini menurut Sardiman (2009: 95) dapat dibangkitkan dengan cara - cara sebagai berikut:

a. Membangkitkan suatu kebutuhan

b. Menghubungkan dengan persoalan pengalaman yang lampau

c. Memberi kesempatan untuk mendapatkan hasil yang baik

d. Menggunakan berbagai macam bentuk mengajar.

Menurut Dalyono (2001: 56-57), bahwa minat dapat timbul karena daya tarik dari luar dan juga datang dari hati sanubari. Pendapat - pendapat di atas menunjukkan bahwa minat dapat ditingkatkan dengan daya tarik dari luar, perasaan senang, dan sikap yang positif yang akan dapat meningkatkan kualitas pencapaian hasil belajar siswa dalam bidang studi tertentu.

Dari paparan diatas minat belajar bisa tumbuh dari dalam dan dorongan dari luar yang menumbuhkan rasa senang terhadap pelajaran yang diikutinya. Dengan perasaan senang maka minat belajar akan tumbuh dengan sendirinya sehingga 
materi yang disampaikan guru pada saat proses pembelajaran bisa dengan mudah diterima siswa.

\section{Hasil Belajar}

Menurut Nana Sudjana (2005: 3) hakikat hasil belajar adalah perubahan tingkah laku individu yang mencakup aspek kognitif, afektif, dan psikomotorik. Menurut Nana Sudjana (1989: 38-40) hasil belajar yang dicapai siswa dipengaruhi oleh dua faktor utama yakni faktor dari dalam diri siswa itu dan faktor yang datang dari luar diri siswa atau faktor lingkungan. Faktor yang datang dari diri siswa terutama kemampuan yang dimilikinya. Faktor kemampuan siswa besar sekali pengaruhnya terhadap hasil belajar yang dicapai. Disamping faktor kemampuan yang dimiliki siswa, juga ada faktor lain, seperti motivasi belajar, minat dan perhatian, sikap dan kebiasaan belajar, ketekunan, sosial ekonomi, faktor fisik dan psikis.

Hasil belajar merupakan segala upaya yang menyangkut aktivitas otak (proses berfikir) terutama dalam ranah kognitif, afektif, dan psikomotorik. Proses berfikir ini ada enam jenjang, mulai dari yang terendah sampai dengan jenjang tertinggi (Suharsimi Arikunto, 2003: 114-115). Keenam jenjang tersebut adalah: (1) Pengetahuan (knowledge) yaitu kemampuan seseorang untuk mengingat kembali tentang nama, istilah, ide, gejala, rumus- rumus dan lain sebagainya, tanpa mengharapkan kemampuan untuk menggunakannya. (2) Pemahaman (comprehension) yakni kemampuan seseorang untuk memahami sesuatu setelah sesuatu itu diketahui dan diingat melalui penjelasan dari kata- katanya sendiri. (3) Penerapan (application) yaitu kesanggupan seseorang untuk menggunakan ide- ide umum, tata cara atau metode- metode, prinsip- prinsip, rumus- rumus, teori- teori, dan lain sebagainya dalam situasi yang baru dan kongkret. (4) Analisis (analysis) yakni kemampuan seseorang untuk menguraikan suatu bahan atau keadaan menurut bagian- bagian yang lebih kecil dan mampu memahami hubungan diantara bagianbagian tersebut. (5) Sintesis (synthesis) adalah kemampuan berfikir memadukan bagian- bagian atau unsur- unsur secara logis, sehingga menjadi suatu pola yang baru dan terstruktur. (6) Evaluasi (evaluation) yang merupakan jenjang berfikir paling tinggi dalam ranah kognitif menurut Taksonomi Bloom. Penelitian disini adalah kemampuan seseorang untuk membuat pertimbangan terhadap suatu situasi, nilai atau ide, atas beberapa pilihan kemudian menentukan pilihan nilai atau ide yang tepat sesuai kriteria yang ada (Anas Sudijono, 2005: 50- 52).

Pada pendidikan formal, semua bidang studi dan bidang pendidikan harus memanfaatkan dasar mental yang ada pada tiap anak untuk meningatkan kemampuan mentalnya kearah kematangan dan kedewasaan dalam arti seluasluasnya. Oleh karena itu penyelenggara pendidikan dan pengajaran harus dilaksakan secara teratur, terarah, dan terencana sesuai dengan pengembangan dasar dan kemampuan mental anak, agar tujuan pendidikan dan pengajaran tercapai secara maksimal (Nursid Sumaatmadja, 2001: 2).

\section{Metode Problem Based Learning}

Menurut Duch (1995) dalam Aris Shoimin (2014:130) mengemukakan bahwa pengertian dari model Problem Based Learning adalah: 
Problem Based Learning (PBL) atau pembelajaran berbasih masalah adalah model pengajaran yang bercirikan adanya permasalahan nyata sebagai konteks untuk para peserta didik belajar berfikir kritis dan keterampilan memecahkan masalah serta memperoleh pengetahuan

Adapun tujuan PBL menurut rusman $(2010,238)$ yaitu penguasaan isi belajar dari disipilin heuristic dan pengembangan ketrampilan pemecahan masalah. PBL juga berhubungan dengan belajar tentang kehidupan yang lebih luas (lifewide learning), ketrampilan memaknai informasi, kolaborasi dan belajar tim dan ketrampilan berfikir reflektif dan evaluative

Ada lima proses dalam penerapan metode PBL dan perilaku yang dibutuh oleh pengajar . Adapun tahapan- tahapan tersebut adalah (Sugiyanto, 2010) :

Tabel 1

Sintaksis Model Pembelajaran berbasis masalah

\begin{tabular}{|c|c|c|}
\hline & Fase & Perilaku Pengajar \\
\hline Fase I & $\begin{array}{ll}\text { Memberikan orentasi } & \text { tentang } \\
\text { permasalahannya } & \text { kepada } \\
\text { mahasiswa } & \end{array}$ & $\begin{array}{l}\text { Guru membahas tujuan pembelajaran, } \\
\text { mendeskripsikan dan memotivasi anak didik } \\
\text { agar terlibat dalam kegiatan mengatasi } \\
\text { masalah yang ada. }\end{array}$ \\
\hline Fase 2 & $\begin{array}{l}\text { Mengorganisasikan anak didik } \\
\text { untuk meniliti }\end{array}$ & $\begin{array}{l}\text { Guru membantu anak didik untuk } \\
\text { mendefenisikan dan mengorganisasikan } \\
\text { tugas- tugas belajar yang terkait dengan } \\
\text { pemrmasalahannya. }\end{array}$ \\
\hline Fase 3 & $\begin{array}{l}\text { Membantu menyelidiki secara } \\
\text { mandiri atau kelompok }\end{array}$ & $\begin{array}{l}\text { Guru mendorong anak didik untuk } \\
\text { mendapatkan informasi yang tepat, } \\
\text { melakukan eksperimen dan mencari } \\
\text { penjelasan serta solusi untuk penyelesaian } \\
\text { masalah tersebut. }\end{array}$ \\
\hline $\begin{array}{l}\text { Fase } 4 \\
\text { Aris }\end{array}$ & $\begin{array}{l}\text { Mengembangkan dan } \\
\text { mempresentasikan hasil kerja }\end{array}$ & $\begin{array}{l}\text { Guru membantu anak didik dalam } \\
\text { merencanakan dan menyiapkan hasil- hasil } \\
\text { yang tepat, seperti laporan, rekaman vidio } \\
\text { dan model- model yang mebantu mereka } \\
\text { untuk menyampaikan kepada orang lain } \\
\text { hasil yang mereka dapatkan untuk } \\
\text { menyelesaikan masalah tersebut. }\end{array}$ \\
\hline Fase 5 & $\begin{array}{l}\text { Menganalisis dan mengevaluasi } \\
\text { proses mengatasi masalah }\end{array}$ & $\begin{array}{l}\text { Guru membantu anak didik untuk } \\
\text { melakukan refleksi terhadap inverstigasinya } \\
\text { dan proses-proses yang mereka gunakan. }\end{array}$ \\
\hline
\end{tabular}

Shoimin (2014:132) berpendapat bahwa kelebihan model Problem Based Learning diantaranya:

a. Siswa didorong untuk memiliki kemampuan memecahkan masalah dalam situasi nyata.

b. Siswa memiliki kemampuan membangun pengetahuannya sendiri melalui aktivitas belajar.

c. Pembelajaran berfokus pada masalah sehingga materi yang tidak ada hubungannya tidak perlu dipelajari oleh siswa. Hal ini mengurangi beban siswa dengan menghafal atau menyimpan informasi.

d. Terjadi aktivitas ilmiah pada siswa melalui kerja kelompok. 
e. Siswa terbiasa menggunakan sumber - sumber pengetahuan, baik dari perpustakaan, internet, wawancara, dan observasi.

f. Siswa memiliki kemampuan menilai kemajuan belajarnya sendiri.

g. Siswa memiliki kemampuan untuk melakukan komunikasi ilmiah dalam kegiatan diskusi atau presentasi hasil pekerjaan mereka.

h. Kesulitan belajar siswa secara individual dapat diatasi melalui kerja kelompok dalam bentuk peer teaching

Aris Shoimin (2014:132) berpendapat bahwa selain memiliki kelebihan, model Problem Based Learning juga memilki kelemahan, diantaranya sebagai berikut:

a. Metode Problem Based Learning tidak dapat diterapkan untuk setiap materi pelajaran, ada bagian guru berperan aktif dalam menyajikan materi. Problem Based Learning lebih cocok untuk pembelajaran yang menuntut kemampuan tertentu yang kaitannya dengan pemecahan masalah.

b. Dalam suatu kelas yang memiliki tingkat keragaman siswa yang tinggi akan terjadi kesulitan dalam pembagian tugas.

\section{METODE}

Penelitian ini dilaksanakan di SMP Negeri 1 Buntulia pada kelas VIII B Tahun Ajaran 2018/2019. Pelaksanaan penelitian tindakan kelas ini dilaksanakan pada bulan Oktober-November 2018. Pemilihan SMP Negeri Buntulia sebagai tempat penelitian, didasarkan pada pertimbangan peneliti sebagai salah satu guru pengajar Mata Pelajaran IPS di SMP Negeri 1 Buntulia

Pengambilan subjek penelitian ini didasarkan pada hasil observasi awal dan kesepakatan dengan teman sejawat. Subjek dalam penelitian ini adalah kelas VIII B SMP Negeri 1 Buntulia yang berjumlah 21 orang. Berdasarkan pengamatan kelas ini memiliki permasalahan minat dan hasil belajar yang rendah saat proses pembelajaran berlangsung serta dalam proses pembelajaran siswa terlihat pasif. Hal ini ditandai dengan kondisi siswa dalam proses pembelajaran IPS cenderung tidak mendengarkan dan bahkan asik ngobrol dengan teman sebangku tanpa memperhatikan guru yang mengajar, sehingga siswa tidak mempunnyai minat untuk mengajukan pertanyaan, jawaban maupun menyampaikan ide yang berdapak pada hasil belajar siswa.

Berikut ini langkah-langkah rancangan penelitian yang dilakukan yaitu :

\section{Siklus I}

\section{Perencanaan}

Langkah-langkah yang dilakukan dalam tahap perencanaan sebagai berikut:

a. Peneliti dan teman sejawat menyiapkan Rencana Pelaksanaan Pembelajaran (RPP) yang memuat serangkaian kegiatan pembelajaran dengan menggunakan metode problem based learning

b. Menyiapkan instrumen penelitian yang terdiri dari:

1) Lembar observasi minat belajar

2) Pedoman wawancara siswa

3) Dokumentasi

c. Melakukan koordinasi dengan guru. 


\section{Pelaksanaan dan Tindakan}

a. Pelajaran diawali dengan salam dan presensi.

b. Guru menginformasikan tujuan pembelajaran.

c. Guru menjelaskan mengenai materi yang akan dipelajari dengan menggunakan media yang disesuaikan dengan materi.

c. Guru membentuk kelompok untuk melaksanakan problem based learning

d. Guru memberikan permasalahan untuk dipecahkan semua kelompok.

e. Masing-masing kelompok berdiskusi untuk memecahkan permasalahan.

f. Masing-masing kelompok mempresentasikan hasil diskusi kelompoknya.

g. Secara bersama-sama membuat kesimpulan dari hasil diskusi kelompok.

Pelaksanaan tindakan dilaksanakan dalam beberapa siklus, pada tiap siklus guru menggunakan metode problem based learning dan media yang disesuaikan materi pelajaran. Selanjutnya diberikan evaluasi tiap siklus yang hasilnya sebagai bahan perencanaan dan perbaikan untuk siklus selanjutnya.

\section{Observasi atau Pengamatan}

Kegiatan observasi dilakukan pada waktu penelitian atau pada waktu pelaksanaan tindakan. Observasi dilakukan untuk mengetahui perubahan yang merupakan dampak dari adanya tindakan. Ada tidaknya perubahan dipantau sejak tindakan diberikan. Hal-hal yang perlu diamati meliputi: pengamatan terhadap kegiatan guru dalam penerapan metode problem based learning dan minat belajar siswa selama proses pembelajaran.

\section{Refleksi}

Hasil observasi atau pengamatan terhadap pelaksanaan tindakan dijadikan bahan analisis (refleksi) untuk mengetahui kemajuan minat belajar siswa. Peneliti dan kolaborator melakukan refleksi untuk mengetahui apakah yang terjadi sesuai dengan rancangan skenario, apakah tidak terjadi penyimpangan atau kesalahan prosedur, apakah prosesnya seperti yang diharapkan. Peneliti dan kolaborator juga melihat ketentuan - ketentuan pada lembar obsevasi minat apakah rata-rata persentase indikator minat belajar siswa pada lembar observasi telah mencapai 75\%. Hasil pemikiran reflektif ini selanjutnya digunakan sebagai dasar dalam menentukan putaran atau siklus berikutnya, apakah tindakan yang diberikan akan diteruskan, dimodifikasi, atau disusun rencana yang sama sekali baru jika ternyata belum belum mencapai kriteria keberhasilan tindakan

\section{Siklus II}

Hasil refleksi pada siklus I sangat menentukan perencanaan tindakan pada siklus ke II. Jika sudah terjadi peningkatan sesuai dengan ketercapaian indikator keberhasilan, siklus II hanya sebagai pemantapan pada siklus I. Namun jika peningkatan belum sesuai dengan indikator keberhasilan maka pada siklus II tahap kerjanya seperti siklus I. Namun pada siklus II rencana penelitian disusun berdasarkan hasil refleksi pada siklus I. Siklus ini juga dilakukan untuk memperbaiki pelaksanaan pembelajaran pada siklus I. Penelitian ini akan dilanjutkan ke siklus III apabila pada siklus II target belum tercapai. Siklus ini akan di hentikan jika tercapainya tujuan penelitian ini yaitu meningkatnya minat belajar siswa sesuai dengan indikator keberhasilan. 
Instrumen yang digunakan dalam penelitian ini adalah:

\section{Lembar observasi/pengamatan}

Intrumen observasi digunakan oleh observer, peneliti dan guru melakukan pengamatan minat belajar peserta didik di dalam kelas saat dilakukan tindakan pada proses pembelajaran.

Tabel 1

Kisi-Kisi Lembar Observasi Minat Belajar Siswa

\begin{tabular}{|l|l|l|l|l|l|l|}
\hline \multirow{2}{*}{ No } & \multicolumn{1}{|c|}{ Aspek } & \multicolumn{1}{|c|}{ Indikator } & \multicolumn{3}{|c|}{ Kriteria Penilaian } \\
\cline { 3 - 7 } 1 & Perhatian & $\begin{array}{l}\text { Memperhatikan guru saat } \\
\text { proses pembelajaran }\end{array}$ & & & & \\
\hline 2 & Ingin Tahu & $\begin{array}{l}\text { Menanyakan materi yang } \\
\text { belum dimengerti }\end{array}$ & & & \\
\hline 3 & Keinginan & $\begin{array}{l}\text { Menjawab dan merespon } \\
\text { pertanyaan guru }\end{array}$ & & & \\
\hline 4 & Rasa Senang & Mengerjakan tugas dari guru & & & & \\
\hline
\end{tabular}

Keterangan:

$1=$ Selalu

$2=$ Sering

$3=$ Kadang - kadang

4 = Tidak Pernah

\section{Dokumentasi}

Data yang diperoleh dengan cara dokumentasi yaitu berupa foto, video yang menggambarkan aktivitas yang dilakukan guru dan peserta didik saat tindakan pada proses pembelajaran

\section{Catatan Lapangan}

Catatan lapangan digunakan untuk mencatat segala kejadian selama proses penelitian berlangsung yang meliputi berbagai aspek pembelajaran dikelas, suasana kelas, pengolahan kelas, hubungan interaksi guru dengan siswa.

Analisis data yang digunakan adalah :

\section{Analisis data kualitatif}

Data yang berhasil dikumpulkan melalui observasi dan catatan lapangan dianalisis dengan menggunakan metode analisis dari Miles dan Huberman (Sugiyono, 2009: 337-345). Secara jelas analisis data terdiri dari tiga tahapan kegiatan yaitu:

\section{a. Reduksi Data (data reduction)}

Reduksi data adalah proses merangkum, memilih, dan memfokuskan data pada hal -hal yang penting, sehingga memberikan gambaran yang jelas dan mempermudah peneliti dalam mengumpulkan data.

b. Penyajian Data (data display)

Setelah dilaksanakan reduksi data, maka selanjutnya barulah dilakukan penyajian data. Penyajian data dapat dilakukan dengan bentuk uraian singkat, bagan, dan sejenisnya.

c. Penarikan kesimpulan (conclusion drawing) 
Kesimpulan dalam penelitian ini merupakan suatu temuan baru.

\section{Analisis data Kuantitatif}

Analisis kuantitatif digunakan untuk memberikan gambaran tentang peningkatan hasil belajar siswa. Hasil belajar siswa dihitung persentase ketuntasan menggunakan rumus dari Zainal Aqib, dkk (2009: 41) yaitu berikut ini:

Keterangan:

$$
p=\frac{\sum \text { siswa yang tuntas belajar }}{\sum \text { siswa }} \times 100 \%
$$

$\mathrm{p}=$ persentase

Tabel 2

Kriteria Ketuntasan Hasil Belajar

Presentase Kriteria Hasil Belajar $\quad$ Presentase Kriteria Hasil Belajar $>75$ Siswa Tuntas $>75$ Siswa Tuntas

Berdasarkan tingkat keberhasilan belajar yang diperoleh siswa maka dapat dipresentasekn kedalam kelompok, sebagai berikut:

Tabel 3

Hasil Presentase Pretest Secara Klasikal

\begin{tabular}{|c|c|}
\hline Presentase Hasil Belajar Siswa & Tingkat Hasi Belajar \\
\hline $90 \%-100 \%$ & Sangat Tinggi \\
\hline $80 \%-89 \%$ & Tinggi \\
\hline $70 \%-79 \%$ & Sedang \\
\hline $55 \%-64 \%$ & Rendah \\
\hline $0 \%-54 \%$ & Sangat Rendah \\
\hline
\end{tabular}

Analisis data observasi minat belajar siswa dilakukan dengan langkahlangkah sebagai berikut:

a. Memberikan kriteria pemberian skor terhadap masing-masing diskriptor pada setiap indikator minat belajar siswa yang diamati.

b. Menjumlahkan skor untuk masing-masing indikator minat belajar siswa

c. Mempersentasekan skor minat belajar siswa pada setiap indikator yang diamati dengan menggunakan rumus:

$$
N P=\frac{R}{S M} \times 100 \%
$$

(Ngalim Purwanto, 2004: 102)

Keterangan:

NP = Nilai persen yang dicari atau diharapkan

$\mathrm{R}=$ Skor mentah yang diperoleh siswa

$\mathrm{SM}=$ Skor maskimum ideal dari tes yang bersangkutan

$100=$ Bilangan tetap

Penelitian ini dikatakan berhasil berhasil apabila mampu mencapai kriteria yang telah ditentukan. Zainal Aqib (2009: 41) menyatakan bahwa kriteria tingkat keberhasilan belajar siswa sebesar $75 \%$ sudah tergolong tinggi. Oleh karena itu, untuk mengukur keberhasilan tindakan dalam penelitian ini adalah sebagai berikut: 
1. Penelitian ini dikatakan berhasil apabila rata-rata persentase indikator minat belajar siswa pada lembar observasi mencapai $75 \%$.

2. Penelitian ini dikatakan berhasil apabila $75 \%$ jumlah siswa kelas VIII B memiliki nilai minimal 70 pada mata pelajaran IPS.

\section{PEMBAHASAN}

\section{Siklus I}

Observasi pada siklus I ini dilakukan pada saat pembelajaran berlangsung. Hasil pengamatan terhadap kegiatan guru menunjukkan bahwa pada siklus I guru belum optimal dalam menjelaskan dan mengondisikan pembelajaran dengan metode Problem Based Learning . Guru belum dapat mengontrol kelas dengan baik, masih banyak siswa yang terlihat kurang berantusias mengikuti pembelajaran IPS, dengan begitu siswa masih sibuk dengan kegiatannya sendiri tanpa memperhatikan langsung ketika guru dalam menyampaikan materi. Guru masih kurang mampu membimbing siswa dalam berinteraksi antara siswa dalam menganalisis dan menemukan informasi. Sehingga guru perlu memperhatikan kembali karakteristik siswa dalam berinteraksi sehigga tujuan pembelajaran yang harus dicapai kurang maksimal.

Pengamatan terhadap siswa dilakukan oleh observer pada saat proses pembelajaran berlangsung. Pada saat pembelajaran dimulai, perhatian siswa belum sepenuhnya tertuju pada materi dan hal tersebut berlangsung sampai pada pertengahan kegiatan inti. Antusiasme siswa belum terlihat pada siklus I ini sehingga siswa kurat berminat mengikuti pembelajaran. Beberapa siswa kurang mampu untuk berinteraksi terhadap kelompoknya, diakibatkan kurang percaya diri dan kurang mampu dalam mengalisis tugas informasi yang didapatkan

Pengamatan terhadap minat belajar siswa dilakukan dari awal sampai dengan akhir pembelajaran. Hasil pengamatan terhadap minat belajar siswa pada siklus I menunjukkan belum tingginya minat belajar siswa dalam kegiatan pembelajaran dengan metode pembelajaran Problem Based Learning . Berikut hasil observasi minat belajar siswa secara rinci.

Tabel 4

Hasil Observasi Minat Belajar Siswa Siklus I

\begin{tabular}{|c|c|l|c|c|c|}
\hline No & Aspek & \multicolumn{1}{|c|}{ Indikator } & $\%$ & $\begin{array}{c}\text { Rata - rata \% } \\
\text { Indikator }\end{array}$ & $\begin{array}{c}\text { Kriteria } \\
\text { Keberhasilan }\end{array}$ \\
\hline 1 & Perhatian & $\begin{array}{l}\text { Memperhatikan guru saat } \\
\text { proses pembelajaran }\end{array}$ & 63 & & \\
\cline { 1 - 3 } 2 & Ingin Tahu & $\begin{array}{l}\text { Menanyakan materi yang } \\
\text { belum dimengerti }\end{array}$ & 61 & \multirow{2}{*}{$61 \%$} & $75 \%$ \\
\hline 3 & Keinginan & $\begin{array}{l}\text { Menjawab dan merespon } \\
\text { petanyaan guru }\end{array}$ & 60 & & \\
\cline { 1 - 3 } & Rengerjakan tugas dari & 60 & & \\
\hline
\end{tabular}

Berdasarkan tabel 4 di atas, dapat diketahui bahwa pada siklus I rata-rata persentase indikator minat belajar siswa belum optimal atau belum mencapai kriteria keberhasilan yang ditetapkan yaitu $75 \%$ karena rata-rata persentase 
indikator minat belajar siswa pada siklus I baru mencapai $61 \%$. Adapun persentase tiap indikator minat belajar siswa pada siklus I yaitu perhatian $63 \%$, ingin tahu $61 \%$, keinginan $60 \%$ dan rasa senang $60 \%$. Untuk lebih jelasnya, dapat dilihat pada diagram di bawah ini.

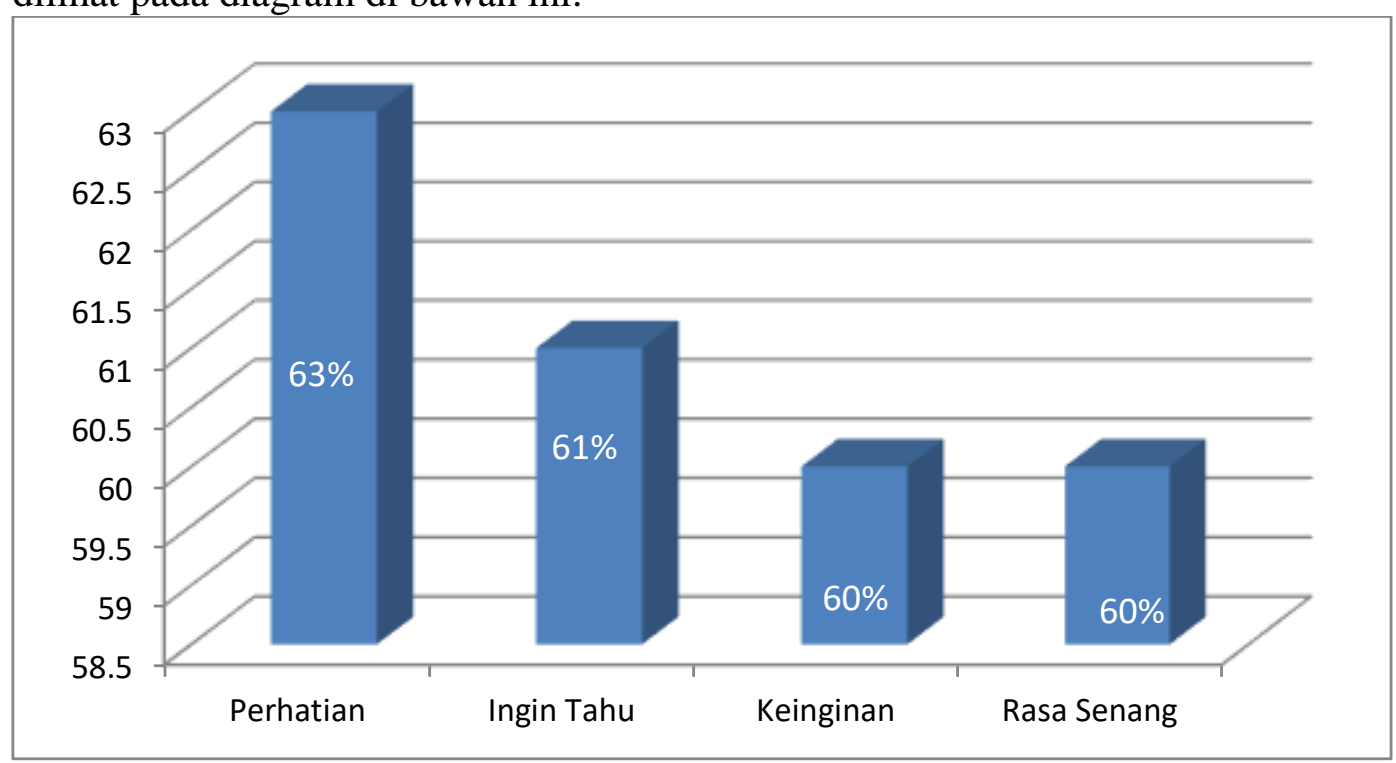

Gambar 1

Diagram MInat Belajar Siklus I

Berdasarkan hasil pemberian tes, dapat terlihat hasil presentase yang diperoleh siswa pada tindakan siklus I table 5 antara lain sebagai berikut:

Tabel 5

Pencapaian Hasil Belajar Yang Di Peroleh Siswa Pada Siklus I

\begin{tabular}{|c|c|c|c|}
\hline Hasil Belajar & Keterangan & Banyak Siswa & Presentase \% \\
\hline Skor $\geq 75$ & Tuntas & 13 & $61,90 \%$ \\
\hline Skor $\leq 75$ & Belum Tuntas & 8 & $38,10 \%$ \\
\hline \multicolumn{2}{|c|}{ Jumlah } & 21 & $100 \%$ \\
\hline
\end{tabular}

Berdasarkan hasil pemberian tes, dapat terlihat hasil belajar yang diperoleh siswa pada tindakan siklus I, antara lain sebagai berikut :

Tabel 6

Hasil Belajar Siklus I

\begin{tabular}{|c|c|c|}
\hline \% Hasil Belajar Siswa & Jumlah Siswa & Tingkat Hasi Belajar \\
\hline $90 \%-100 \%$ & 3 & Sangat Tinggi \\
\hline $80 \%-89 \%$ & 5 & Tinggi \\
\hline $70 \%-79 \%$ & 5 & Sedang \\
\hline $55 \%-64 \%$ & 5 & Rendah \\
\hline $0 \%-54 \%$ & 3 & Sangat Rendah \\
\hline
\end{tabular}

Berdasarkan tabel 6 di atas, dapat diketahui bahwa jumlah siswa yang mencapai nilai KKM pada siklus I sebanyak 13 siswa dari 21 siswa atau sudah mencapai persentase $61,90 \%$. Oleh karena itu belum berhasil mencapai kriteria 
keberhasilan yang ditetapkan yaitu $75 \%$. Sedangkan $38,10 \%$ siswa yang belum mencapai KKM ada sebanyak 8 siswa. Apabila tabel hasil belajar siswa siklus I di atas dibuat diagramnya, maka akan tampak sebagai berikut.

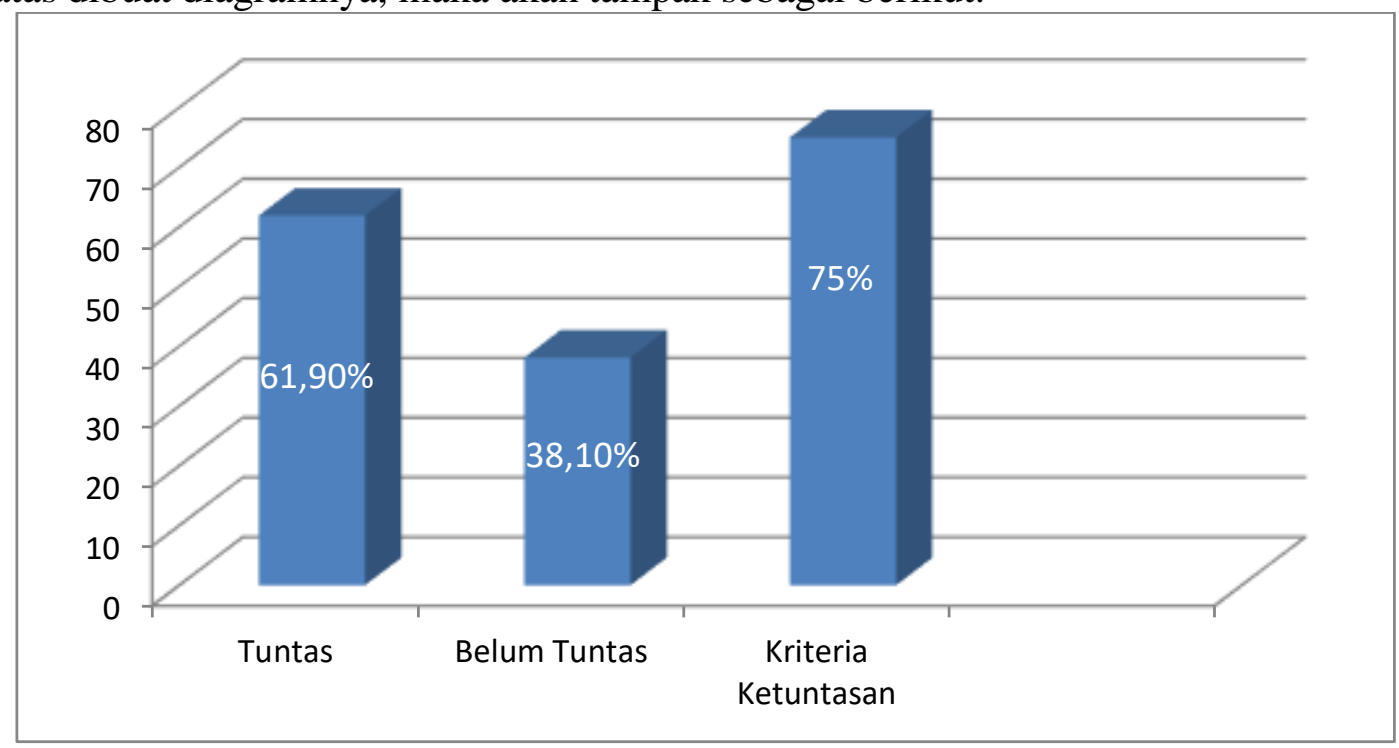

Gambar 2.

Diagram Hasil Belajar Siklus I

\section{Siklus II}

Pengamatan terhadap kegiatan guru pada siklus II menunjukkan bahwa guru sudah dapat melakukan kegiatan pembelajaran dengan baik dalam penerapan metode Problem Based Learning. Pengelolaan kelas yang dilakukan oleh guru dalam siklus II ini jauh lebih baik dibandingkan siklus I. Guru sudah mampu menjelaskan dan mengorganisasikan pembelajaran aktif dengan metode Problem Based Learning secara lebih baik. Selain itu guru juga memberikan dorongan seperti memberikan motivasi kepada siswa untuk menumbuhkan minat belajar siswa di dalam kelas.

Siswa terlihat lebih berminat dalam proses pembelajaran di dalam kelas. Siswa terlihat sangat bersemangat. Siswa juga lebih berani dalam menyampaikan ide maupun pendapatnya dalam menjawab pertanyaan guru. Selain itu siswa juga lebih berani bertanya. Siswa yang pada siklus sebelumnya terlihat pasif juga sudah mulai aktif. Pada kegiatan akhir, siswa berpartisipasi aktif dengan cara menyimpulkan materi pelajaran bersama dengan guru hal ini menunjukan bahwa minat belajar sisiwa sudah baik sesuai dengan indikator minar belajar yang diukur.

Secara umum pengamatan terhadap minat belajar siswa dalam mengikuti kegiatan pembelajaran pada siklus II terlihat mengalami peningkatan dari siklus I. Peningkatan dari siklus I tersebut mengakibatkan rata-rata persentase minat belajar siswa pada siklus II mencapai kriteria keberhasilan tindakan yang telah ditetapkan. Hal tersebut terlihat pada tabel di bawah ini. 
Tabel 7

Hasil Observasi Minat Belajar Siswa Siklus II

\begin{tabular}{|c|c|c|c|c|c|}
\hline No & Aspek & Indikator & $\%$ & $\begin{array}{l}\text { Rata - rata \% } \\
\text { Indikator }\end{array}$ & $\begin{array}{c}\text { Kriteria } \\
\text { Keberhasilan }\end{array}$ \\
\hline 1 & Perhatian & $\begin{array}{l}\text { Memperhatikan guru saat } \\
\text { proses pembelajaran }\end{array}$ & 82 & \multirow{4}{*}{$80 \%$} & \multirow{4}{*}{$75 \%$} \\
\hline 2 & Ingin Tahu & $\begin{array}{l}\text { Menanyakan materi yang } \\
\text { belum dimengerti }\end{array}$ & 79 & & \\
\hline 3 & Keinginan & $\begin{array}{l}\text { Menjawab dan merespon } \\
\text { petanyaan guru }\end{array}$ & 81 & & \\
\hline 4 & Rasa Senang & Mengerjakan tugas dari guru & 77 & & \\
\hline
\end{tabular}

Berdasarkan tabel 7 di atas, dapat diketahui bahwa pada siklus II rata-rata persentase indikator minat belajar siswa sudah optimal atau sudah mencapai kriteria keberhasilan yang ditetapkan yaitu $75 \%$ karena rata-rata persentase indikator minat belajar siswa pada siklus II mencapai $80 \%$. Adapun persentase tiap indikator minat belajar siswa pada siklus I yaitu perhatian $82 \%$, ingin tahu $79 \%$, keinginan $81 \%$ dan rasa senang $77 \%$. Untuk lebih jelasnya, dapat dilihat pada diagram di bawah ini.

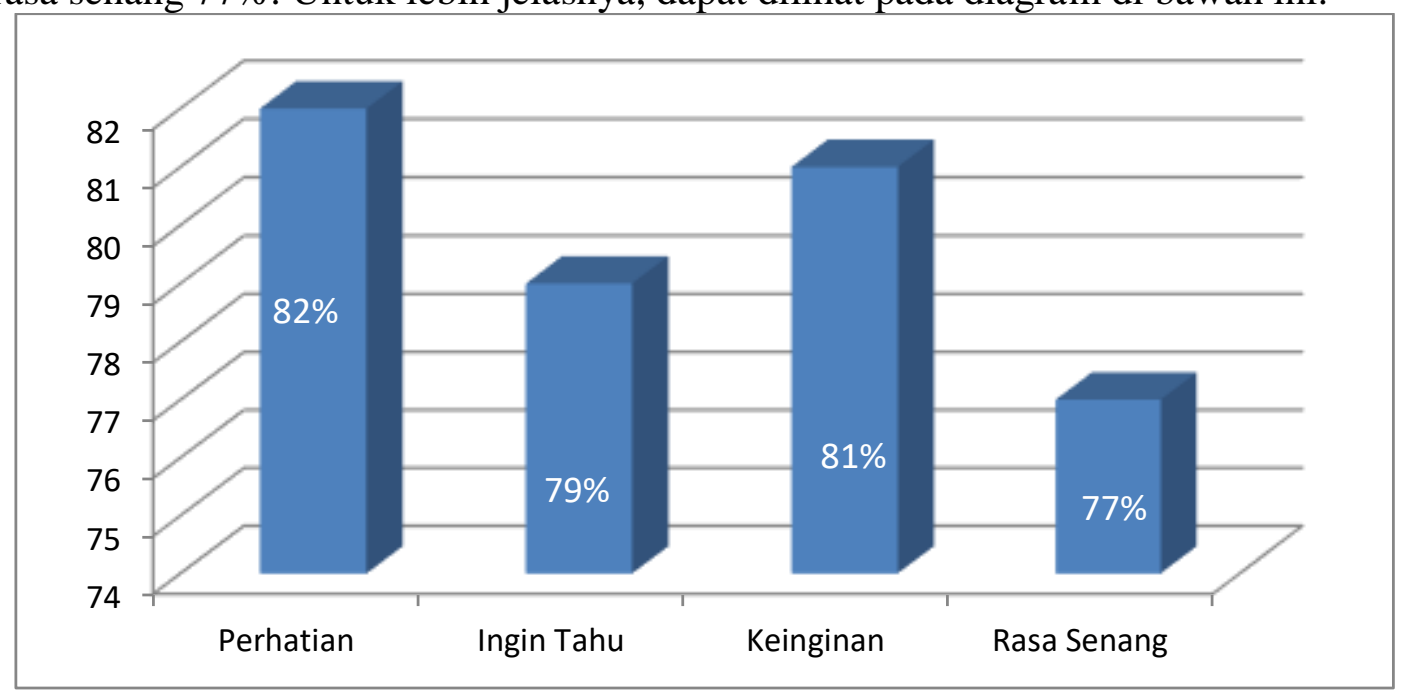

Gambar 3.

Diagram Minat Belajar Siklus II

Berdasarkan hasil pemberian tes, dapat terlihat hasil presentase yang diperoleh siswa pada tindakan siklus II table 8 antara lain sebagai berikut:

Tabel 8

Pencapaian Hasil Belajar Yang Di Peroleh Siswa Pada Siklus II

\begin{tabular}{|c|c|c|c|}
\hline Hasil Belajar & Keterangan & Banyak Siswa & Presentase \% \\
\hline Skor $\geq 75$ & Tuntas & 18 & $85,71 \%$ \\
\hline Skor $\leq 75$ & Belum Tuntas & 3 & $14,29 \%$ \\
\hline \multicolumn{2}{|c|}{ Jumlah } & 21 & $100 \%$ \\
\hline
\end{tabular}

Berdasarkan hasil pemberian tes, dapat terlihat hasil belajar yang diperoleh siswa pada tindakan siklus II, antara lain sebagai berikut : 
Tabel 9

Hasil Belajar Siklus II

\begin{tabular}{|c|c|c|}
\hline$\%$ Hasil Belajar Siswa & Jumlah Siswa & Tingkat Hasi Belajar \\
\hline $90 \%-100 \%$ & 8 & Sangat Tinggi \\
\hline $80 \%-89 \%$ & 10 & Tinggi \\
\hline $70 \%-79 \%$ & 2 & Sedang \\
\hline $55 \%-64 \%$ & 1 & Rendah \\
\hline $0 \%-54 \%$ & - & Sangat Rendah \\
\hline
\end{tabular}

Berdasarkan tabel 9 di atas, dapat diketahui bahwa jumlah siswa yang mencapai nilai KKM pada siklus II sebanyak 18 siswa dari 21 siswa atau sudah mencapai persentase $85,71 \%$. Oleh karena itu belum berhasil mencapai kriteria keberhasilan yang ditetapkan yaitu $75 \%$. Sedangkan $14,29 \%$ siswa yang belum mencapai KKM hanya 3 siswa. Hal ini mengidentifikasikan bahwa hasil belajar yang diperoleh dengan pemberian tes kepada siswa dapat dikategorikan tinggi.Apabila tabel hasil belajar kelompok siklus II di atas dibuat diagramnya, maka akan tampak sebagai berikut.

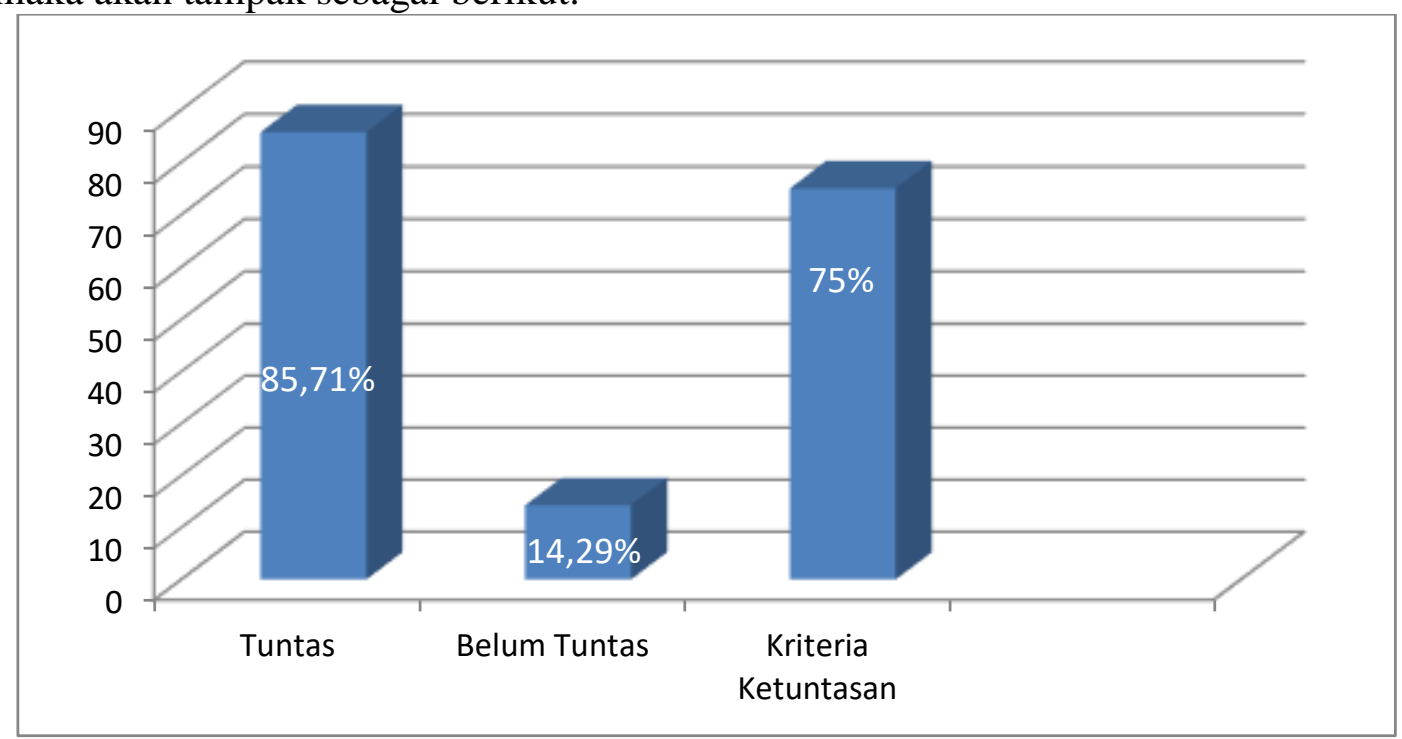

Gambar 4.

Diagram Hasil Belajar Siklus II

Berdasarkan tabel dan diagram diatas telah menunjukkan peningkatan yang baik, dengan begitu siswa dinyatakan sudah berhasil dalam mengikuti pembeljaran IPS dengan metde Problem Based Learning karena telah memenuhi hasil belajar yang diharapkan yaitu memenuhi indikator keberhasilan yang sudah ditentukan. Dengan demikian penelitian dikatakan berhasil dan tidak perlu lagi dilanjutkan pada siklus berikutnya

Maka dengan begitu dapat diberikan kesimpulan bahwa dengan diterapkan metode pembelajaran Problem Based Learning dalam pembelajaran IPS pada kelas VIII B di SMP Negeri 1 Buntulia Tahun Pelajaran 2018/2019, dikatakan berhasil dan meningkatkan minat dan hasil belajar yang sangat signifikan sesuai tujuan yang diharapkan. 


\section{Kesimpulan}

Berdasarkan hasil deskripsi dan paparan data sebagaimana dikemukakan dapat dikemukakan simpulan penelitian sebagai berikut:

1. Penerapan metode pembelajaran Problem Based Learning dapat meningkatkan minat dan hasil belajar siswa dalam pembelajaran IPS dikelas VIII B SMP Negeri 1 Buntulia. Hal tersebut dibuktikan dengan adanya peningkatan ratarata persentase indikator minat belajar siswa setiap siklusnya. Pada siklus I rata - rata persentase indikator minat belajar siswa adalah 61\%. Pada siklus II mengalami peningkatan sebesar $19 \%$ sehingga menjadi $80 \%$. Hal ini berarti bahwa rata-rata persentase indikator minat belajar siswa telah melampaui kriteria keberhasilan tindakan yang ditetapkan yaitu $75 \%$.

2. Penerapan metode pembelajaran Problem Based Learning dapat meningkatkan hasil belajar siswa. Hal ini dibuktikan dengan persentase siswa yang mencapai nilai KKM pada siklus I sebesar $61,90 \%$ meningkat menjadi $85,71 \%$ pada siklus II. Hal ini berarti bahwa jumlah siswa yang mencapai nilai KKM (70) telah melampaui kriteria keberhasilan yang ditetapkan yaitu $75 \%$.

\section{DAFTAR PUSTAKA}

Agus Sujanto. 2004. Psikologi Umum. Jakarta: PT. Rineka Cipta.

Aqib, Zainal. 2009. Evaluasi Pembelajaran. Bandung: PT Remaja Rosdakarya

A.M Sardiman. 2009. Interaksi dan Motivasi Belajar Mengajar. Jakarta: PT. Rajawali Pers

Anas Sudijono. 2005. Pengantar Evaluasi Pendidikan. Jakarta: Paja Grafindo Persada.

Arikunto, Suharsimi. 2003. Prosedur Penelitian Suatu Praktek. Jakarta: Bina Aksara

Aris Shoimin. 2014. Model Pembelajaran Inovatif Dalam Kurikulum 2013. Yokyakarta: AR-ruz media

Bakar, Rosdiana. 2014. Pendidikan Suatu Pengantar. Medan: Citapustaka Media Perintis

Dalyono. 2001. Psikologi Pendidikan. Jakarta : Rineka Cipta

Djaali. 2008. Psikologi Pendidikan. Jakarta: Bumi Aksara.

Haidir \& Salim. 2014. Strategi Pembelajaran. Medan: Perdana Publshing

Huda, Miftahul, 2014. Model-Model Pengajaran dan Pembelajaran. Yogyakarta: Pustaka Pelajar. 
Iskandar Agung. 2014. Panduan Penelitian Tindakan Kelas Bagi Guru. Jakarta: Bestari Buana Murni.

Ngalim Purwanto. 2004. Prinsip-Prinsip dan Teknik Evaluasi Pengajaran. Bandung : Rosdakarya.

Rosdiana A. Bakar. 2012. Pendidikan Suatu Pengantar, Medan: Cita Pustaka Media Perintis

Slameto. 2013. Belajar dan Faktor-faktor yang Mempengaruhinya. Jakarta: Prineka Cipta.

Sudjana, Nana. 2005. Dasar-dasar Proses Belajar Mengajar. Bandung. Sinar Baru Algensindo

Sugiyono. 2009. Metode Penelitian Kuantitatif, Kualitatif dan R\&D. Bandung : Alfabeta.

Suhana, Cucu. 2014. Konsep Strategi Pembelajaran. Bandung: PT Refika Aditama.

Syah, Muhibbin. 2002. Psikologi Belajar. Jakarta: PT. Raja Grafindo Persada

Trianto. 2015. Model Pembelajaran Terpadu. Jakarta: Bumi Aksara 